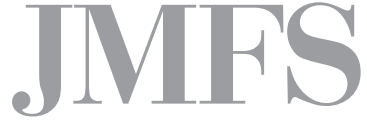

Journal of Management and Financial Sciences
Volume XI

Issue 32 (June 2018)

pp. $9-26$

Warsaw School of Economics

Collegium of Management and Finance

Maria Aluchna

Collegium of Management and Finance

SGH Warsaw School of Economics

Emilia Tomczyk

Collegium of Economic Analysis

SGH Warsaw School of Economics

\title{
Compliance with Corporate Governance Best Practice. The Perspective of Ownership Structure
}

ABSTRACT

The article examines compliance with corporate governance best practice in the post transition economy addressing the heterogeneity of interests of different shareholders. On the basis of the agency theory, we suggest that in the concentrated ownership environment the principal-principal conflict results in lower compliance with the corporate governance code. More specifically, since compliance with best practice requires introducing independent directors and in that sense shifts control from shareholders to the board, we hypothesize that companies characterized by concentrated ownership and the dominant position of the founder/individual investor are reluctant to comply with board governance best practice. To evaluate our hypotheses, we explore compliance with board governance best practice with respect to the presence of independent directors, formation of an audit committee and other specialized board committees (remuneration, risk, strategy). We test the link between the compliance with the code and the ownership structure. Our analysis supports the principal-principal conflict argument and shows that companies with concentrated ownership and founder control do not comply with the board governance best practice. We believe this article contributes to the existing literature twofold. Firstly, we identify the patterns of corporate governance best practice implementation in the post socialist, post transition, emerging economy and depict the dynamics of the compliance with the code guidelines. Secondly, we show that the principal-principal conflict addresses the compliance policy of listed companies and results in various approaches to corporate governance conformity. 
Keywords: Corporate governance, best practice, compliance, Poland JEL classification Codes: M2, P3

\section{Introduction}

Corporate governance remains one of the most extensively researched theme in management and finance academic literature, experiencing a dynamic development in practice and regulation. It aims to protect investors, minimize risk and provide for long-term sustainable value [Mallin, 2004]. These goals are, at the company level, understood as providing an adequate structure of checks and balances [Monks, Minow, 2004] and are exemplified in the form of best practice [Tricker, 2012]. The codes of best practice are a voluntary set of principles, recommendations and standards relating to internal corporate governance and addressing the most problematic inefficiencies [Tricker, 2012; Chizema, 2008]. The codes address selected dimensions of corporate governance, such as the board's functioning, shareholder rights, transparency, auditing, remuneration [OECD, 2004, 2015], and provide principles and norms to assure creating shareholder value.

The research on corporate governance codes addressed questions of dynamics, motivation and effectiveness of compliance [Arcot et al., 2010; Andres, Theissen, 2008] and non-compliance [MacNeil, Li, 2006] with the code guidelines, the impact of the country's legal regime on the adoption and the efficiency of the code [Zattoni, Cuomo, 2008; Cuervo, 2002], and the impact of compliance on a firm's performance and stock valuation [Goncharov et al., 2006]. The studies refer to either the impact of a single selected recommendation, the general compliance/non-compliance with the reported explanations, or the quality of a firm's corporate governance measured by the inclusion into an index or rating. As the research focuses on the impact of the macro-environment on the formulation, the scope and the standards of the compliance with the code [Chizema, 2008; Andres, 2008], very few studies address the aspects of organizational characteristics or dynamics upon the code adoption.

The existing literature offers a series of studies on the political economy of formulation of the code guidelines, the dynamics of their adoption and the scale and scope of the compliance with the code enhancing the understanding of the interplay between soft law and self-regulation, listed companies, their executives and managers. The integration of the code guidelines is also embedded in the national specificities of corporate governance. The studies, however, address a limited number of companies and refer mostly to the effectiveness of the code in the United Kingdom [Arcot et al., 2010; MacNeil, Li, 2006] and Germany [Chizema, 2008; Goncharov et al., 2006; Andres, Theissen, 2008; Cromme, 2005; Werder et al., 2005]. They do not cover other countries, ignoring developing, transition or emerging markets, with some exceptions for Central and Eastern Europe [Hermes et al., 2007; Bistrowa, Lace, 2012]. 
They also fail to explain the impact of a firm's characteristics and national specifics on the formulation of the codes and the compliance with their recommendations. Thus, we believe there is a gap in the existing literature on the corporate governance conformity in the context of company characteristics, particularly ownership structure. The compliance with best practice represents a firm and its shareholder decision to follow a set of standards which determine the internal governance limiting or adding responsibilities to various stakeholders. Consequently, the decision on the compliance is heavily embedded in the shareholders' and executives' awareness of corporate governance issues, their capabilities to implement guidelines and the openness to constrain themselves while overseeing and managing the firm. This, to a large extent, depends on the organizational characteristics, particularly the ownership structure, which determines the division of power and control amongst shareholders and executives. Moreover, firms of different ownership structures and various constellations of shareholders may react differently to changes and implementations of new norms as provided by corporate governance codes [Cuervo, 2002; Chizema, 2008]. This is more likely to be visible in the context of post-transition economy characterized by weaker institutional order, weaker investor protection, diversified shareholder structures and companies of different origin.

In this paper we intend to fill this gap in the existing literature. Our goal is to identify links between company compliance with corporate governance best practice and their characteristics with respect to ownership structure and origin in the context of the post-transition, post-socialist economy. We analyze the hand-collected data on the sample of Polish listed companies for the period 2008-2012, measured every two years. We focus on the selected best practice (formation of an audit committee, formation of other board committees and the presence of independent directors on the board). Based on the analysis, we are able to identify leaders and laggards of corporate governance compliance with regard to company characteristics, ownership structure, origin and sector of operation. Our analysis indicates that the type of the dominant shareholder matters with respect to the company's compliance with corporate governance best practice. The article is organized as follows. First, the concept of best board governance practice and compliance is presented. Then, in the context of principal-principal conflicts, we formulate hypotheses on the links between shareholder structure and compliance with board governance best practice. Later the research methodology and results are presented, followed by the discussion of findings. Final remarks are provided in the conclusion part.

\section{Compliance with the corporate governance code}

The analysis of the formulation, adoption and compliance with the best practice codes is placed in the center of the legal and economic debate on corporate governance based on self-regulation and the enforcement of legal obligations of companies [Arcot et al., 2010]. The code of best practice consists of a set of recommendations and guidelines regarding corporate governance of a firm viewed as the reaction to company mismanagement and ineffective 
governance [Cuervo, 2002]. In general, the codes aim at increasing accountability of directors, strengthening shareholder protection and enhancing transparency [Mallin, 2004; Tricker, 2012; OECD, 2004, 2015]. In particular, the guidelines address the functioning and the composition of the board, formation of specialized board committees and formulation of director duties. The recommendations also refer to compensation schemes, with the special concern given to the pay size and structure, bonuses and incentive programmes, the time horizon of the variable component, functioning of the remuneration committee and disclosure. Best practice recommends equal rights of all shareholders and defines standards of transparency.

The codes of corporate governance are viewed as an additional set of norms or a mechanism which increases executive accountability and mitigates the agency conflict [Hermes et al., 2007; Dedman, 2002]. The compliance is meant to increase investors' trust [Arcot et al., 2010] and lower the risk associated with a company's operation [Bistrowa, Lace, 2012]. The compliance may add to the investor relations or transparency standards stipulated by law and may play a role of corporate governance mechanism based on the public information disclosed to investors. The existing literature provides evidence that the quality of governance code improves a firm's image and reputation. Although the pricing effect may be subject to a more complex relationship, in general the code conformity is positively related to performance and value, as investors appreciate the adoption of the best practice [Gompers et al., 2003; Bhagat, Bolton, 2008; Vander Bauwhede, 2009].

The role of the code and compliance is heavily dependent on the governance mechanism used by a given national system. In general, the codes appear to be more effective in countries with a stronger stock market. Cuervo [2002] notes the specifics of continental European corporate governance based on concentrated ownership, pyramidal structures and business groups requires the adoption of best practice more intensively than Anglo-Saxon governance systems. However, the "lower enforceability of norms in Continental Europe lowers the applicability of good governance" [Cuervo, 2002]. The data from Germany indicates that the compliance with the code may also have an interactive effect within the national system of corporate governance. As argued by Goncharov et al. [2006], the code and disclosure of the declaration of conformity with its guidelines to the stock market filled the control vacuum in the internal governance after the withdrawal of the commercial banks from an active corporate monitoring in Germany.

The best practice codes are of particular importance for corporate governance in emerging and transition countries. The specificity of corporate governance in transition and emerging markets formulates unique tasks and challenges for the best practice initiative. As long as the codes in developed markets provide fine tuning recommendations to mitigate monitoring and incentive inefficiencies, they play a crucial role in emerging economies, setting the agenda for their reforms and further development. Corporate governance guidelines constitute an element of the new regulatory regime and represent a political decision for social and economic convergence with the global stock market. Post socialist countries underwent a significant transition process. Starting with the Romanian initiative in 2000 as the first code in the CEE 
region, the positive spillovers of the best practice code encouraged listed companies to implement a series of recommendations and to integrate them into the governance structures. The initiative was taken over by the Czech Republic (2001), Poland, Russia, the Slovak Republic (2002), Macedonia and Ukraine (2003), Lithuania, Slovenia and Hungary (2004), Latvia (2005) and Estonia (2006), being followed by the codes' amendments and subsequent versions [Hermes et al., 2007]. As a result, the adoption of widely recognized best practice is aimed at the improvement of the oversight quality, strengthening of the investor and shareholder protection and enhancement of transparency standards. In addition, the corporate governance system in transition and emerging markets is found to be insider dominated, closed and based on hierarchies combined with poorly developed external mechanisms and weak investor protection. The structure of corporate governance in transition economies is the outcome of the political choices made during the reform process and still remains in the development phase, revealing significant variations amongst countries and companies [Bistrowa, Lace, 2012].

Transition and emerging economies are characterized by significant ownership concentration, separation of control and cash flow rights resulting from the adoption of pyramids and formation of business groups, domination of families and insiders [Berglöf, Pajuste, 2005]. Yet, these economies pursue corporate governance reforms and aspire to get integrated with the global stock market. Such conditions offer a unique environment for testing the adoption of and compliance with corporate governance codes and the post-transition, post-socialist Polish economy. The Polish stock market is the largest in the CEE region in terms of both the number of companies and the capitalization and appears to be a perfect laboratory for studying governance choices with respect to the shareholder structure. The comparative analysis on CEE countries places Poland in the bottom of the region in terms of the code content. As observed by Hermes et al. [2007], Polish codes covered 7 out of 18 recommendations according to OECD Principle. This places Polish codes in between the top scoring countries such as the Czech Republic (16 of 18) and the lowest ranked such as Romania (3 of 18) as measured by the number of OECD recommendations covered by the national code. Polish companies were also ranked low with respect to the transparency standards [Berglöf, Pajuste, 2005]. However, the research by Onofrei [2009] placed Poland first in terms of the enforcement of OECD corporate governance principles. Poland was followed by Lithuania, Latvia and Slovenia (tied in the second place) and Croatia (the third place).

\section{Compliance and ownership structure}

The literature on corporate governance emphasizes the role of ownership structure viewed as one of the essential elements determining company strategy [Tihanyi et al., 2003; van Essen et al., 2015] and governance and supervision practice [Shleifer, Vishny, 1997; Soren, Turnbull, 2012; Bozec et al., 2013]. Thus, the codes of best practice address a similar list of corporate governance matters, such as board work, executive compensation, transparency and 
shareholder rights. Despite the adopted "one size fits all" approach, these recommendations may not necessarily appeal to shareholders and stakeholders in various institutional and company settings. Arcot et al. [2010] argue that with the fundamental rule of the flexibility principle companies are given the discretion whether (and if the answer is yes, in what aspects) they decide to comply. The decision may be different, depending on shareholder constellations with respect to the number of shareholders, their activism and investment strategies, their identities and the degree of ownership and control concentration. In general, the formulation of the codes of best practice is motivated by the need and strategy to improve corporate governance and mitigate structural shortcomings [Aguilera, Cuervo-Cazurra, 2004]. Yet, the content of the recommendations is driven by and addresses the expectations of institutional shareholders. Therefore, the recommendations may be differently viewed and may be of various usage in different ownership settings.

Among the code guidelines, the board recommendations are viewed as the critical element of corporate governance due to the power and responsibilities of board directors [Cuervo, 2002]. The board that selects, appoints and monitors executives, reviews and guides corporate strategy, determines the dividend policy, monitors the effectiveness of the company's governance practices, ensures the integrity of the corporation's accounting and financial reporting systems and oversees the process of disclosure and communication [Sheridan, 2001]. It is the board who bears the ultimate accountability for the company's performance. Boards "are the link between the people who provide capital (the shareholders) and the people who use that capital to create value (the managers)" and become liaisons between shareholders of different identities who exert the residual rights and executives who constitute the powerful group that runs and controls the company. The board is viewed as the crucial element of each corporate governance system, both at the national and company levels, determining the scale and scope of economic and social development. Additionally, the function of a board director belongs to the elite professions requiring experience, knowledge and integrity. As argued by Colley et al. [2003], the directors are to fulfill a given set of tasks, which involve the obligation to represent the interest of the owners who cannot represent themselves.

The integration of the code guidelines with the firm's actors and stakeholders is likely to be differentiated by two main dimensions of ownership structure: the concentration of ownership and control as well as the presence of various shareholder types. Ownership concentration represents the situation when one majority shareholder controls the company's shares. The existing literature uses the threshold of $20 \%$ of shares to distinguish the majority shareholder [La Porta et al., 1999]. Concentrated ownership significantly impacts the corporate governance practice; majority owners provide important control mechanisms and reduce the principal-agent conflict between shareholders and executives [Faccio, Lang, 2002]. Ownership concentration allows for the access to company information, assures appointment of board directors and provides monitoring over executives' work [Shleifer, Vishny, 1997]. Ownership concentration may substitute other corporate governance mechanisms provided by the stock market or the activism of institutional investors. Majority shareholders, however, may engage 
in entrenching activities abusing minority shareholder rights [Morck, R., Yeung, 2004; Nenova, 2003]. This is particularly important in transition and emerging economies characterized by weak institutional enforcement and insufficient investor protection [Berglöf, Claessens, 2006]. Large shareholders are less interested in the share price increase and are less sensitive to the stock market [Berglöf, Pajuste, 2005]. In contrast, dispersed ownership translates into the presence of various small and fragmented investors, who cannot deliver adequate governance mechanisms and to a larger extent rely on the stock market and widely recognized guidelines. Therefore, we formulate hypothesis 1 .

\section{H1: Concentrated ownership is negatively related to compliance with the board best practice}

Recently, the literature on ownership structure has started to examine the heterogeneity of shareholder interest, investigating differences in investment strategy and the time horizon of various shareholder types [Su et al., 2008]. The shareholder identity determines his/her engagement in governance and expectations towards the company. This may also influence the strategy towards compliance with best practice. In particular, the best practice code to a large extent represents the expectations of financial investors, who rely on internationally recognized guidelines and standards [Mallin, 2004]. They appreciate the code conformity as the signal for better governance, larger transparency and lower risk. Financial investors are also often the active group submitting corporate governance proposals referring to board work, shareholder rights, transparency and executive compensation [Larcker, Tayan, 2011]. Thus, we propose hypothesis $\mathrm{H} 2$.

\section{H2: The presence of a financial investor in ownership structure is positively related to compliance with the board best practice}

The founder is a separate shareholder identity distinguished in studies on ownership structure in emerging and transition economies as many companies are relatively recently established. The literature on founder-controlled companies remains limited but often refers to family-controlled firms. These companies are expected to be directed and controlled by the founders who reveal strong vision, long term horizon, charismatic leadership and engagement in the firm's operation [Barontini, Caprio, 2006]. This is often in opposition to short-term oriented financial or fragmented investors. Founder- and family-controlled companies rely on the mechanism based on the individual stamina, which is often viewed as the substitute to the more institutionalized procedures in the case of other company types [Anderson, R., Reeb, 2003; Chu, 2009]. Better informed founders may also engage in entrenchment activities and strive for sustaining control [Morck, R., Yeung, 2004]. Therefore, we argue that founders develop less formalized governance and to a lesser extent rely on code guidelines, and propose hypothesis $\mathrm{H} 3$.

\section{H3: The presence of an individual shareholder/founder in ownership structure is negatively related to compliance with the board governance best practice}




\section{Empirical research}

\subsection{Data}

We test the link between the compliance with board governance best practice and the ownership structure on the sample of 100 largest companies listed on the Warsaw Stock Exchange for the period 2008-2012. Due to the low variance in the characteristics of shareholder structure and compliance, the data was collected every two years, that is, in 2008, 2010 and 2012. The initial data base covered 100 companies of the largest market capitalization in 2012 and then was expanded to include the earlier periods. As several companies had their IPOs in 2009 or 2010, while six companies engaged in M\&A transactions in 2013 and 2014, there are some missing variables, particularly for 2008. The total sample consists of 283 observations. The data on ownership structure and performance was obtained from EMIS data base, internet portal bankier.pl as well as from annual reports of the companies. The data on compliance with the board governance best practice was hand-collected from the statements of conformity of corporate governance best practice, which are attached to the annual report and publicly available on investor relations websites.

We are particularly interested in the data on the board best practice with respect to the following issues:

- The best practice of the presence of at least 2 independent directors on the supervisory board.

- The best practice of the formation of the audit committee within the supervisory board.

- The best practice of the formation of the remuneration and other committees within the supervisory board.

These board guidelines appear to be the most problematic best practices of WSE listed companies differentiating the degree of compliance [Aluchna, 2009; Aluchna, 2015; Campbell et al., 2009].

On the basis of the data set available, we defined several dependent variables reflecting the degree of compliance with the best practice code.

1. Binary variable equal to 1 if the number of independent directors is equal to or larger than 2 (that is, the company complies with the corporate governance best practice code) and 0 otherwise (variable ind_directors_01).

2. Binary variable equal to 1 if the remuneration committee is established within the company and 0 otherwise (variable remun_cm).

3. Three binary variables reflecting the degree of compliance with the corporate governance best practice code:

- binary variable equal to 1 if the company conforms with all the best practices and 0 otherwise (variable cg_max)

- binary variable equal to 1 if the company conforms with more than one best practice and 0 otherwise (variable $c g \_$med) 
- binary variable equal to 1 if the company conforms with at least one best practice and 0 otherwise (variable $\mathrm{cg}$ _min).

The following company-specific explanatory variables are available to explain firms' compliance with the best practice code:

- branch of industry in 12 categories: construction; chemical industry; electric machine and machine industry; energy sector; finance; food, trade and security sector; information technology (ICT); metal industry; clothing industry; postal services; mining industry; food industry (variable ind1)

- branch of industry in four basic categories: heavy industry, light industry, services, finance (variable ind2)

- company assets, million Polish zł (variable assets)

- percentage share of the largest shareholder (variable share_cont)

- type of shareholder: State Treasury; domestic industry; foreign industry; individual investor; financial investor (variable share_type)

- board size (variable board_size)

- functioning of audit committee within the board (variable audit_cm)

- net profit, Polish zł (variable net_profit)

- return on assets (variable roa)

- dividend yield (variable $d y$ )

- number of employees (variable employees)

- age of enterprise (variable age)

- privatization status: 1 - privatized, 0 - established after 1989 (variable privatization)

- ownership status: 1 - institutional or dispersed investor, 0 - controlled by an individual or a family directly or indirectly by an individual or a family via a financial or industry investor (variable truly_listed)

Additionally, for the purpose of the econometric analysis, on the basis of variables listed above, additional binary variables were constructed:

- the binary variables for each of the 12 categories of variable ind1 (ind1_1, .., ind1_12)

- the binary variables for each of the 4 categories of variable ind 2 (ind $2 \_1, \ldots$, ind 244 )

- the binary variable for the financial sector: 1 if $i n d 1 \_5=1$ and 0 otherwise (ind1_5only)

- on the basis of the percentage share of the largest shareholder (share_cont):

- binary variable equal to 1 if share_cont> 50 and 0 otherwise (share_50)

- binary variable equal to 1 if share_cont> 30 and 0 otherwise (share_30)

- on the basis of the shareholder type (share_type): five binary variables for each of the shareholder categories:

- binary variable equal to 1 for State Treasury and 0 otherwise (type_1)

- binary variable equal to 1 for domestic industry and 0 otherwise (type_2)

- binary variable equal to 1 for foreign industry and 0 otherwise (type_3)

- binary variable equal to 1 for individual investor and 0 otherwise (type_4)

- binary variable equal to 1 for financial investor and 0 otherwise (type_5) 
- on the basis of the size of the audit committee (audit_cm):

- binary variable equal to 1 if the company does not inform about the functioning of the audit committee within the board and 0 otherwise (audit_0)

- binary variable equal to 1 if the whole board functions as the audit committee and 0 otherwise (audit_1)

- binary variable equal to 1 if the formed audit committee functions within the board and 0 otherwise (audit_2)

To limit the degree of multicollinearity between the explanatory variables, linear correlation coefficients were calculated for the quantitative variables (that is, assets, percentage shares of the largest shareholder, the number of employees, net profit, return on assets, and dividend yield). The highest correlation coefficients, ranging from 0.68 to 0.78 across the period analyzed, were found for the following pairs of variables: assets and the number of employees; net profit and the number of employees; net profit and ROA. Consequently, in the subsequent stages of the empirical analysis special attention will be given to the issue of multicollinearity of variables reflecting assets, net profit, the number of employees and ROA.

While a wide set of potential explanatory variables is available, only a few of the companies' characteristics exhibit any impact on the degree of their compliance with the best practice code, as the next section demonstrates.

\subsection{Dynamics of compliance}

As an introduction to the econometric analysis of the factors influencing the adoption of the best practice code, the dynamics of compliance with the selected best practices is presented in Table 1.

Table 1. Dynamics of compliance with the corporate governance best practice code

\begin{tabular}{|l|l|l|l|}
\hline \multicolumn{1}{|c|}{ Variable } & 2008 & 2010 & 2012 \\
\hline ind_directors_01 =1 & $51 \%$ & $56 \%$ & $58 \%$ \\
\hline remun_cm =1 & $32 \%$ & $37 \%$ & $51 \%$ \\
\hline cg_max $=1$ & $26 \%$ & $30 \%$ & $38 \%$ \\
\hline$c g$ med $=1$ & $28 \%$ & $49 \%$ & $59 \%$ \\
\hline cg_min $=1$ & $60 \%$ & $76 \%$ & $82 \%$ \\
\hline no. of observations & 87 & 97 & 99 \\
\hline
\end{tabular}

Source: the authors' own calculations.

It follows from Table 1 that the percentages of the companies complying with the board governance best practice have been increasing over the analyzed period. More specifically, the percentage of the companies employing at least two independent directors increased from $51 \%$ in 2008 to $58 \%$ in 2012, and the percentage of the companies with the remuneration committee grew from $32 \%$ in 2008 to $51 \%$ in 2012 . In relative terms, the improvement in compliance with 
the remuneration committee rule is noticeably higher than with the independent directors rule (19 percentage points versus 7 percentage points). The degree of compliance with the board governance best practice, as measured by the binary index variables, has been increasing over time in all categories, with $82 \%$ companies conforming with at least one best practice in 2012 . However, only $38 \%$ companies conformed with the strict guidelines in 2012.

\subsection{Logit models of compliance with the corporate governance best practice code}

To analyze the influence of a company's individual characteristics on the probability that it follows a good practice rule, binary logit models were estimated. For all dependent variables - that is, for all the measures of compliance with the best practice code - the following general results emerge. The probability of adopting a good practice rule is not influenced, with very few exceptions, in a statistically significant way by:

- financial variables such as ROA, dividend yield, or net profit, whether included in nominal terms or per employee;

- sector of operation, whether classified into 4 or 12 categories or separated into financial and non-financial sectors;

- general company characteristics such as its age, number of employees, privatization status, or ownership status.

On the other hand, the following variables exhibit statistically significant effects - although varying from year to year and across the measures of compliance - on the acceptance of board governance best practices:

- size of the company as measured by its assets;

- concentration of ownership;

- existence of audit and remuneration committees;

- presence of an individual investor versus other shareholder types.

Table 2. Estimation results of the logit model; dependent variable: ind_directors_01

\begin{tabular}{|c|c|c|c|}
\hline & 2008 & 2010 & 2012 \\
\hline Assets & $1.16043 e-08^{\star *}$ & $1.21062 \mathrm{e}-08^{* *}$ & 8.39772e-09* \\
\hline share_50 & $-0.218854^{*}$ & $-0.196889 *$ & -0.0290142 \\
\hline audit_0 & $-0.518236^{\star \star}$ & -0.277808 & -- \\
\hline audit_2 & $-0.347106^{\star \star}$ & $-0.218908^{*}$ & -- \\
\hline remun_cm & -- & -- & $0.270206^{\star \star}$ \\
\hline McFadden pseudo-R ${ }^{2}$ & 0.252914 & 0.141760 & 0.144306 \\
\hline count $\mathrm{R}^{2}$ & $73.9 \%$ & $63.9 \%$ & $70.7 \%$ \\
\hline mean of dependent variable & 0.500000 & 0.556701 & 0.585859 \\
\hline
\end{tabular}

Source: the authors' own calculations.

Marginal effects calculated at means of variables; ${ }^{*}$ - variable significant at the 0.1 significance level, ${ }^{\star *}$ - variable significant at the 0.05 significance level. 
In Table 2, marginal effects and basic statistics for the logit model of independent directors, estimated by the Maximum Likelihood method with QML standard errors are presented.

It follows from Table 2 that a company's assets positively and consistently (across three years considered) influence the probability of employing at least two independent directors on the board. Also, in 2008 and 2010 the concentration of ownership reflected in variable share_50 (that is, whether the largest shareowner owns more than $50 \%$ of the company's stock) proves to be statistically significant. Yet, its impact on the dependent variable, as measured by the marginal effect, decreases from 2008 to 2010 and ceases to be statistically significant in 2012 . This may be explained by the increase in the conformity with the best practice or may be the impact of the financial crisis. The formation of an audit committee proves significant for employing at least two independent directors in 2008 and 2010 and loses its significance to the existence of a remuneration committee in 2012. The change is mostly likely driven by the shift of these guidelines to hard law which resulted in the increase of its adoption. All three models exhibit similar and acceptable classification power reflected in the count $\mathrm{R}^{2}$ measures. The 2008 model is distinguished by relatively high McFadden's pseudo- $\mathrm{R}^{2}$ coefficient in comparison to 2010 and 2012 models. 2010 and 2012 may appear to be more difficult to be modeled, most likely due to the impact of the crisis. In general, the evidence provides partial support for hypothesis H1 (in 2008 and 2010 for independent directors and an audit committee and in 2012 for a remuneration committee) and is consistent with our argumentation assuming the existence of the principal-principal conflict.

In Table 3, marginal effects and basic statistics for the logit model of the existence of a remuneration committee are presented.

Table 3. Estimation results of the logit model; dependent variable: remun_cm

\begin{tabular}{|c|c|c|c|}
\hline & 2008 & 2010 & 2012 \\
\hline In_assets & $0.0701366^{\star \star \star}$ & $0.0762885^{\star \star \star}$ & $0.174995^{\star \star \star}$ \\
\hline roa & -- & $1.00390 * *$ & -- \\
\hline type_4 & -- & $-0.370725^{\star \star \star}$ & $-0.470636^{\star \star \star}$ \\
\hline share_50 & -- & -- & $-0.234843^{\star}$ \\
\hline McFadden pseudo- $\mathrm{R}^{2}$ & 0.075056 & 0.199566 & 0.144306 \\
\hline count $R^{2}$ & $73.9 \%$ & $73.2 \%$ & $80.8 \%$ \\
\hline mean of dependent variable & 0.306818 & 0.371134 & 0.505051 \\
\hline
\end{tabular}

Source: the authors' own calculations.

Marginal effects calculated at means of variables; ${ }^{*}$ - variable significant at the 0.1 significance level, ${ }^{*}$ - variable significant at the 0.05 significance level.

As shown in Table 3, the factors that significantly influence whether a company established a remuneration committee are different from the factors significant in the case of independent directors. Moreover, the models estimated for the remuneration committee dependent variable exhibit no stability whatsoever: sets of explanatory variables change every year, and only logs of a company's assets remain a statistically significant and positive influence across 
the years. A remuneration committee is more often to be found in larger companies which usually have larger boards. It is also viewed as a more "advanced" best practice still scoring very low compliance amongst Polish listed companies. In 2010 and 2012, the presence of individual investors decreases the probability of the company's forming a remuneration committee, which partially supports hypothesis $\mathrm{H} 3$ and is consistent with the argumentation on the principal-principal conflict. Count $\mathrm{R}^{2}$ coefficients for all the models presented in Table 3 are acceptable, but McFadden's $\mathrm{R}^{2}$ 's are considerably lower than in the models estimated for the independent directors dependent variable. While not directly comparable, these results suggest that it is more difficult to identify factors responsible for the decision of establishing a remuneration committee than for the decision of employing at least two independent directors.

The models of probability of meeting the best practice criteria in terms of an adequate number of independent directors (Table 2) or the existence of a remuneration committee (Table 3) reflect only the selected elements of the set of the best practice rules. To arrive at more general conclusions, logit models for aggregated variables $c g \_m a x$, $c g \_m e d$ and $c g \_m i n$ were estimated. In Table 4, the summary of estimation results is presented, with signs of the marginal effects and significance of variables reported.

Table 4. Estimation results of the logit model; dependent variables: $c g \_m a x, c g \_m e d$ and $c g \_$min

\begin{tabular}{|c|c|c|c|c|c|c|c|c|c|}
\hline & \multicolumn{3}{|c|}{2008} & \multicolumn{3}{|c|}{2010} & \multicolumn{3}{|c|}{2012} \\
\hline & cg_min & cg_med & cg_max & cg_min & cg_med & cg_max & $c g \_$min & cg_med & cg_max \\
\hline In_assets & $+/ * \star \star$ & $+/ * \star \star$ & $+/ * \star \star$ & $+/ * \star \star$ & $+/ * \star \star$ & $+/ * \star$ & $+/ * \star$ & $+/ * \star \star$ & $+/ * \star \star$ \\
\hline$d y$ & - & + & + & $+/ * \star *$ & + & + & $-/ * \star *$ & - & + \\
\hline truly_listed & - & - & - & - & + & + & - & + & + \\
\hline privatization & + & - & $-I^{*}$ & - & - & - & + & - & - \\
\hline type_4 & - & $-1^{\star \star}$ & $-/^{* *}$ & $-1^{* *}$ & $-/^{* *}$ & $-1^{* *}$ & $-/^{* *}$ & $-1^{\star *}$ & $-1^{*}$ \\
\hline share_50 & - & + & - & $-/^{\star *}$ & - & - & $-/^{* *}$ & - & - \\
\hline McFadden pseudo- $\mathrm{R}^{2}$ & 0.1047 & 0.1932 & 0.2046 & 0.3949 & 0.2272 & 0.1776 & 0.2523 & 0.377 & 0.2404 \\
\hline count $R^{2}$ & $67 \%$ & $72 \%$ & $75 \%$ & $88 \%$ & $73 \%$ & $77 \%$ & $88 \%$ & $78 \%$ & $76 \%$ \\
\hline mean of dependent variable & 0.6023 & 0.375 & 0.2613 & 0.7629 & 0.4948 & 0.2989 & 0.8181 & 0.5858 & 0.3838 \\
\hline
\end{tabular}

Source: the authors' own calculations.

Marginal effects calculated at means of variables, signs only reported; ${ }^{*}$ - variable significant at the 0.1 significance level, ${ }^{* *}-$ variable significant at the 0.05 significance level.

The only explanatory variable that consistently and significantly (and positively) influences the probability of a company's compliance with the best practice code is its size reflected in logs of assets. This can be explained by the argumentation that larger companies have a larger board and for them it is easier to comply with the board governance best practice. Due to the board size, having independent directors on board or formation of specialized board committees does not lower the power of the majority shareholder. With the sole exception of the 2008 
model for dependent variable $\mathrm{cg}$ _ $\min$, the presence of an individual investor consistently and significantly decreases the probability of the company's compliance. This finding supports hypothesis $\mathrm{H} 3$ and illustrates the heterogeneity of shareholders' interests. Partial support can be also found for hypothesis $\mathrm{H} 1$, assuming a negative link between compliance and ownership concentration. Interestingly, we observe no impact of the financial investors in the ownership structure on the degree of compliance. Thus, there is no support for hypothesis H2. Other factors that occasionally reveal a statistically significant impact on dependent variables reflecting aggregate compliance with the best practice code include concentration of ownership, privatization status and dividend yield - although the last variable behaves strangely: it changes its sign between 2010 and 2012 and influences only the variable cg_min, that is, the most reluctant approach to the acceptance of the best practice code.

To summarize, designing a comprehensive model for all the measures of compliance considered and all three data points proved infeasible. However, a few common features emerge: the size of a company, measured by assets or logs of assets, and concentration of ownership remain the two single most influential variables across the models.

\section{Discussion}

The analysis provided verification for the formulated hypotheses on the link between ownership structure (concentration, presence of a financial investor and presence of an individual shareholder/founder) and the compliance with the best practice guidelines. On the basis of logit models we find that it is difficult to design a statistically acceptable model for either of the measures of compliance with corporate good practice, and if such a model is found, it is not stable across the period analyzed or across various measures of compliance. Only a handful of a company's characteristics exhibit a statistically significant impact on whether it decides to adopt certain elements of the best practice code. These characteristics include the size of a company (reflected in assets or logs of assets), concentration of ownership (whether the largest shareowner owns more than $50 \%$ of the company's stock), establishment of audit and remuneration committees, ROA, and controlled by an individual investor. In models with aggregated good practices dependent variables, dividend yield and privatization status are also significant in some of the years under consideration.

Summarizing the results, we observe that the compliance with the best practice is linked both to the ownership concentration and the presence of an individual shareholder/founder in the ownership structure. In particular, we note that:

- ownership concentration (at the threshold of 50\% of shares) is linked to lower compliance with the guidelines on the presence of independent directors on the board (for 2008 and 2010);

- ownership concentration (at the threshold of $50 \%$ of shares) is linked to lower compliance with the guidelines on the formation of an audit committee (for 2008 and 2010); 
- ownership concentration (at the threshold of $50 \%$ of shares) is linked to lower compliance with the guidelines on the formation of a compensation committee (for 2012 only);

- ownership concentration (at the threshold of $50 \%$ of shares) is linked to lower compliance with the guidelines as measured by the corporate governance index (for 2010 and 2012);

- the presence of an individual shareholder/founder in ownership structure is linked to lower compliance with the guidelines as measured by the corporate governance index (for 2008, 2010 and 2012).

These findings partially support hypotheses H1 and H3. Simultaneously, we do not find any impact on the presence of financial investors in shareholder structure. These results are consistent with the argumentation on the principal-principal conflict [Su et al., 2008], showing that the majority shareholder, particularly a private investor, is less likely to adopt best practice of the board's functioning. Referring to practical and policy implications, the results support the "impracticality of one size fits all" argued by Davies [2008], not only referring to the differences between countries but also to differences between companies with respect to their characteristics, particularly their ownership structure.

We believe this analysis contributes to the existing literature on corporate governance codes, focusing on the compliance with the board guidelines. Our contribution is twofold. First, we identify the patterns of corporate governance best practice implementation in the post-socialist, post-transition, emerging economy. We depict the dynamics of the corporate governance best practice implementation. As the results indicate, over the analyzed 7-year period we observe a constant and steady improvement in the compliance with board governance best practice. Secondly, we link the compliance with corporate governance code with a firm's characteristics, particularly the origin and ownership structure with respect to the ownership concentration and dominant shareholder identity. We argue that the principal-principal conflict addresses the compliance policy of listed companies and results in various approaches to corporate governance conformity Our findings reveal that companies characterized with ownership concentration and companies controlled by the founders or individual investors report the lowest compliance with board governance best practice. As for the hypothesis of interest difference of heterogeneous shareholders, we show that the type of the dominant shareholder matters with respect to the company compliance with the corporate governance best practice. These findings suggest that the adoption of board recommendation is rather perceived as the loss of power and decision making and is not viewed as the legitimization mechanisms for firms with the majority individual shareholder.

\section{Summary}

The paper's aim is to identify links between company characteristics, particularly ownership structure and compliance with corporate governance guidelines on the board's functioning. Following the argumentation of the agency theory we assume the compliance with the board 
governance best practice may be subject to the principal-principal conflict. As we observe that the compliance with best practice related to the ownership concentration and the presence of individual shareholder/founder in the ownership structure, we argue that the heterogeneity of shareholders' interests impact the corporate governance strategy adopted by a company. A possible direction would be the extension of data series with respect to the time of the observation and the size of the sample to examine the dynamics over time. Additionally, more detailed data of a firm's characteristics, including ownership structure would allow addressing questions on the impact of the various shareholders puzzle on the corporate governance practice. Finally, the further analysis could address the question on a possible substitution of the formal compliance with the board governance best practice and other governance mechanisms in companies controlled by a founder/individual investor.

\section{References}

1. Aguilera R., Cuervo-Cazurra A., 2004. Codes of good governance worldwide: What is the trigger? Organization Studies, Vol. 25, pp. 415-443.

2. Aluchna M., 2009. Implementation of best practice code. Practical implications from Warsaw Stock Exchange. Social Responsibility Journal, Vol. 5, pp. 123-140.

3. Aluchna M., 2015. Własność a corporate governance [Ownership and corporate governance]. Wydawnictwo Poltext, Warszawa.

4. Anderson R., Reeb D., 2003. Founding family ownership and firm performance: Evidence from the S\&P 500. Journal of Finance, Vol. 58, pp. 1301-1329.

5. Andres Ch., Theissen E., 2008. Setting a fix to keep the geese - Does the comply-or-explain principle work? Journal of Corporate Finance, Vol. 14, pp. 289-301.

6. Arcot S., Bruno V., Faure-Grimaud C., 2010. Corporate governance in the UK: Is the comply or explain approach working. International Review of Law and Economics, Vol. 30, pp. 193-201.

7. Barontini R., Caprio L., 2006. The effect of family control on firm value and performance. Evidence from continental Europe. European Financial Management, Vol. 12, pp. 689-723.

8. Berglöf E., Claessens S., 2006. Enforcement and good corporate governance in developing countries and transition economies. World Bank Research Observer, Vol. 21, pp. 123-150.

9. Berglöf E., Pajuste A., 2005. Why do firms disclose and why? Enforcing corporate governance and transparency on Central and Eastern Europe. Oxford Review off Economic Policy, Vol. 21, pp. 178-197.

10. Bhagat S., Bolton J., 2008. Corporate governance and firm performance. Journal of corporate Finance, Vol. 14, pp. 257-273.

11. Bistrowa J., Lace N., 2012. Corporate governance best practice and stock performance: Case of CEE companies. Systemics, Cybernetics and Informatics, Vol. 10, pp. 63-69.

12. Bozec R., Dia M., Bozec Y., 2013. Corporate ownership and governance practices in Canada: a longitudinal study. International Journal of Corporate Governance, Vol. 4, pp. 51-73. 
13. Campbell K., Jerzemowska M., Najman K., 2009. Corporate governance challenges in Poland: Evidence from comply or explain disclosures. Corporate Governance, Vol. 9, pp. 623-634.

14. Chizema A., 2008. Institutions and voluntary compliance: The disclosure of individual executive pat in Germany. Corporate Governance, Vol. 16, pp. 359-374.

15. Chu W., 2009. The influence of family ownership on SME performance: Evidence from public firms in Taiwan. Small Business Economics, Vol. 33, pp. 353-373.

16. Colley J., Doyle J., Logan G., Stettinius W., 2003. Corporate Governance. McGraw-Hill.

17. Cromme G., 2005. Corporate Governance in Germany and the German Corporate Governance Code. Corporate Governance, Vol. 13, pp. 362-367.

18. Cuervo A., 2002. Corporate governance mechanisms: a plea for less code of good governance and more market control. Corporate Governance, Vol. 10, pp. 84-93.

19. Davies M., 2008. The impracticality of an international 'one size fits all' corporate governance code of best practice. Managerial Auditing Journal, Vol. 23, pp. 532-544.

20. Dedman E., 2002. The Cadbury Committee recommendations on corporate governance - a review of compliance and performance impacts. International Journal of Management Reviews, Vol. 4, pp. 335-352.

21. Faccio M., Lang L., 2002. The ultimate ownership in Western European corporations. Journal of Financial Economics, Vol. 65, pp. 365-395.

22. Gompers P., Ishii J., Metrick A., 2003. Corporate governance and equity prices. The Quarterly Journal of Financial Economics, Vol. 118, pp. 107-155.

23. Goncharov I., Werner J., Zimmermann J., 2006. Does compliance with the German corporate governance code have an impact on stock valuation? An empirical analysis. Corporate Governance, Vol. 14, pp. 432-445.

24. Hermes N., Postma T., Zivkov, O., 2007. Corporate governance codes and their contents: An analysis of Eastern European codes. Journal for East European Management Studies, Vol. 12, pp. 53-74.

25. La Porta R., Lopez-de-Silanes F., Shleifer A., 1999. Corporate ownership around the World. Journal of Finance, Vol. 54, pp. 471-517.

26. Larcker D., Tayan B., 2011. Corporate Governance Matters. Pearson Education.

27. MacNeil I., Li X., 2006. Comply or explain: market discipline and non-compliance with the Combine Code. Corporate Governance, Vol. 14, pp. 486-496.

28. Mallin Ch., 2004. Corporate Governance. Oxford University Press, Oxford.

29. Monks R., Minow N., 2004. Corporate Governance. Blackwell Business.

30. Morck R., Yeung B., 2004. Family control and the rent-seeking society. Entrepreneurship Theory and Practice, Vol. 28, pp. 391-409.

31. Morck R., 2004. How to eliminate pyramidal business groups - the double taxation of intercorporate dividends and other incisive uses of tax policy. Tax Policy and the Economy, Vol. 19.

32. Nenova T., 2003. The value of corporate voting rights and control: A cross-country analysis. Journal of Financial Economics, Vol. 68, pp. 325-351.

33. OECD, 2015. G20/OECD Principles of Corporate Governance, http://www.oecd.org/daf/ca/ Corporate-Governance-Principles-ENG.pdf [accessed January 9th, 2016]. 
34. OECD, 2004. Principles Of Corporate Governance, http://Www.Oecd.Org/Corporate/Ca/ Corporategovernanceprinciples/31557724.Pdf, [accessed January 9th, 2016].

35. Sheridan A., 2001. A view from the top: women on the boards of public companies. Corporate Governance, Vol. 1, pp. 8-14.

36. Shleifer A., Vishny R., 1997. A survey of corporate governance. Journal of Finance, Vol. 52, pp. 737-783.

37. Soren C., Turnbull S., 2012. What's wrong with corporate governance best practices? In Baker, H. \& Anderson. A. eds. Corporate Governance. A Synthesis of Theory, Research and Practice. John Willey and Sons, New Jersey, pp. 79-96.

38. Su Y., Xu D., Phan P., 2008. Principal-principal conflict in the governance of the Chinese public corporation. Management and Organization Review, Vol. 4, pp. 17-38.

39. Tihanyi L., Johnson R., Hoskisson R., Hitt M., 2003. Institutional ownership differences and international diversification: The effect of boards of directors and technological opportunity. Academy of Management Journal, Vol. 46, pp. 105-211.

40. Tricker B., 2012. Corporate Governance. Principles, Policies and Practices. Oxford University Press, Oxford.

41. van Essen M., Carney M., Gedajlovic E., Heugens P., 2015. How does family control influence firm strategy and performance? A meta-analysis of US publicly listed firms. Corporate Governance: An International Review, Vol. 23, pp. 3-24.

42. Vander Bauwhede H., 2009. On the relation between corporate governance compliance and operating performance. Accounting and Business Research, Vol. 39, pp. 497-513.

43. Werder A., Talaulicar T. Kolat G., 2005. Compliance with the German Corporate Governance Code: an empirical analysis of the compliance statements by German listed companies. Corporate Governance, Vol. 13, pp. 178-187.

44. Zattoni A., Cuomo F., 2008. Why adopt codes of good governance? A comparison of institutional and efficiency perspective. Corporate Governance, Vol. 16(1), pp. 1-15. 